\title{
SARS-CoV-2 seropositivity after infection and antibody response to mRNA-based vaccination
}

\section{Emily J. Ciccone, MD, MHS ${ }^{1}$, Deanna R. Zhu, BA ${ }^{2}$, Rawan Ajeen, BSPH ${ }^{2}$, Evans K. Lodge, BA, BS ${ }^{2}$, Bonnie E. Shook-Sa, DrPH ${ }^{3}$, Ross M. Boyce MD, MSc ${ }^{1}$, Allison E. Aiello, PhD, MS ${ }^{2 *}$, and the COVID HCP Study Team}

\begin{abstract}
${ }^{1}$ Division of Infectious Diseases, School of Medicine, University of North Carolina
${ }^{2}$ Department of Epidemiology, Gillings School of Global Public Health, University of North Carolina

${ }^{3}$ Department of Biostatistics, Gillings School of Global Public Health, University of North Carolina
\end{abstract}

\section{COVID HCP Study Team (alphabetical order):}

- Haley Abernathy, BS - Institute for Global Health and Infectious Diseases, University of North Carolina

- Naseem Alavian, MD, MHS - Department of Hospital Medicine, School of Medicine, University of North Carolina

- Cherese Beatty, MPH - Department of Epidemiology, Gillings School of Global Public Health, University of North Carolina

- Christy Chung, BA - Institute for Global Health and Infectious Diseases, University of North Carolina

- Haley E. Garrett, BS - Department of Epidemiology, Gillings School of Global Public Health, University of North Carolina

- Jonathan J. Juliano, MD, MSPH - Division of Infectious Diseases, School of Medicine, University of North Carolina

- Elise King, BA - Institute for Global Health and Infectious Diseases, University of North Carolina

- Alena J. Markmann, MD, PhD - Division of Infectious Diseases, School of Medicine, University of North Carolina

- Carmen E. Mendoza, BS - Department of Epidemiology, Gillings School of Global Public Health, University of North Carolina

- Raquel Reyes, MD, MPA - Department of Hospital Medicine, School of Medicine, University of North Carolina

- Jasmine L. Taylor, MPH - Institute for Global Health and Infectious Diseases, University of North Carolina

- David J. Weber, MD, MPH - Division of Infectious Diseases, School of Medicine, University of North Carolina

Manuscript word count (including abstract, references, and table/figure captions): 1,494

${ }^{*}$ Corresponding Author Information:

Gillings School of Global Public Health, CB \#7435, Chapel Hill, NC 27599, USA

Email: aaiello@email.unc.edu 
medRxiv preprint doi: https://doi.org/10.1101/2021.02.09.21251319; this version posted February 22, 2021. The copyright holder for this preprint

(which was not certified by peer review) is the author/funder, who has granted medRxiv a license to display the preprint in perpetuity.

All rights reserved. No reuse allowed without permission.

\begin{abstract}
The effect of SARS-CoV-2 infection on response to mRNA-based SARS-CoV-2 vaccines is not well-described. We assessed longitudinal SARS-CoV-2-specific antibody responses pre- and post-vaccination among individuals with and without prior infection. The antibody response to the first vaccine dose was almost two-fold higher in individuals who were seropositive before vaccination compared to those who were seronegative, suggesting that prior infection primes the immune response to the first dose of mRNA-based vaccine.
\end{abstract}


medRxiv preprint doi: https://doi.org/10.1101/2021.02.09.21251319; this version posted February 22, 2021. The copyright holder for this preprint (which was not certified by peer review) is the author/funder, who has granted medRxiv a license to display the preprint in perpetuity. All rights reserved. No reuse allowed without permission.

The impact of prior SARS-CoV-2 infection on antibody response to mRNA-based vaccines has not yet been well-characterized. The Centers for Disease Control and Prevention (CDC) recently suggested that individuals with documented immunity might defer vaccination for 90 days to expedite access for those without immunity, but data supporting these guidelines are limited. ${ }^{1}$ Specifically, there are few studies describing the response to vaccination among previously infected individuals. Early reports suggest that prior infection may prime the immune response to the first vaccine dose, but these reports did not assess longitudinal changes in antibody levels before vaccination. ${ }^{2-4}$ This information is important as the timing of natural infection and fluctuations in immunity over time may impact the vaccine response. ${ }^{5,6}$ Here, we examined longitudinal SARS-CoV-2 antibody responses among healthcare personnel (HCP) with and without evidence of prior infection to examine the effect of natural infection on vaccination response.

We conducted a longitudinal observational cohort study of HCP at a large academic medical center, which began enrolling in July 2020. Its purpose was to examine risk factors for infection and identify changes in antibodies to SARS-CoV-2 over time. ${ }^{7}$ The study was approved by the University of North Carolina Institutional Review Board (20-0942), and informed consent was obtained from all participants. Enrolled individuals provided blood samples every two weeks for the first 12 weeks and monthly thereafter. mRNA-based SARS-CoV-2 vaccinations (PfizerBioNTech [BNT162b2] and Moderna [mRNA-1273]) were available to HCP from the insitution starting in mid-December 2020 or earlier through vaccine trials. For all pre- and post-vaccination samples, we measured total immunoglobulin antibodies specific to the receptor binding domain of the SARS-CoV-2 spike protein by ELISA as previously described. ${ }^{8}$ We used a positive to negative ratio $(\mathrm{P} / \mathrm{N})$ cut-off of 2.57 to ensure $99.5 \%$ specificity per CDC recommendations for SARS-CoV-2 serology assays. ${ }^{9}$ Exact Wilcoxon rank sum tests with corresponding $95 \%$ confidence intervals $(\mathrm{Cl})^{10}$ were used to compare median $\mathrm{P} / \mathrm{N}$ levels between seropositive and seronegative participants and change in $\mathrm{P} / \mathrm{N}$ for those with paired pre- and post-vaccination measurements.

As of February 17, 2021, the study has enrolled 213 HCP with 194 (91\%) providing at least one blood sample. One individual was excluded from this analysis due to co-enrollment in a SARSCoV-2 treatment trial. Table 1 presents the cohort demographics. Five participants (3\%) had antibodies to SARS-CoV-2 at their baseline study visit, herein "prevalent seropositive" (Figure 1a). Notably, one demonstrated persistent seropositivity for over six months, while another remained seropositive for more than three months before reverting to seronegative one month prior to vaccination. Five participants (3\%) became seropositive during the study, herein "incident seropositive" (Figure 1a); four of those five individuals (80\%) reported COVID-19 symptoms prior to seroconversion.

Most participants $(97 \%, 187 / 193)$ received at least one dose of a SARS-CoV-2 mRNA-based vaccine as part of the institution's vaccination program or through a vaccine trial. Antibody measurements after at least one vaccine dose were available for $60 \%(6 / 10)$ of seropositive and $48 \%(87 / 183)$ of seronegative participants. One individual tested positive for SARS-CoV-2 by PCR shortly after the second vaccine dose $\left(V_{2}\right)$; post $-V_{2}$ results were excluded for this participant. We compared antibody responses to the first vaccine dose between participants who were seropositive (at any point) and those who were seronegative prior to vaccination (Figure 1b). Figure 1b shows that seropositive individuals developed an almost two-fold higher antibody response to their first vaccine dose (median $\mathrm{P} / \mathrm{N}=13.8$ ) compared to those who were seronegative (median $\mathrm{P} / \mathrm{N}=7.6$; difference estimate 6.53 (95\% $\mathrm{Cl}: 1.6-10.4)$, Wilcoxon test statistic $(W)=227, p=0.014)$. Additionally, the post $-V_{1}$ antibody response in seropositive participants was of similar magnitude to the post $-V_{2}$ response among seronegative participants 
medRxiv preprint doi: https://doi.org/10.1101/2021.02.09.21251319; this version posted February 22, 2021. The copyright holder for this preprint (which was not certified by peer review) is the author/funder, who has granted medRxiv a license to display the preprint in perpetuity. All rights reserved. No reuse allowed without permission.

(post- $\mathrm{V}_{1}$ seropositive median $\mathrm{P} / \mathrm{N} 13.8$ vs. post- $\mathrm{V}_{2}$ seronegative 12.2; difference estimate 1.68 (95\% Cl: $-3.3-6.0), W=202, p=0.462)$. The absolute magnitude of the increase in antibody levels from pre-vaccination to post- $\mathrm{V}_{1}$ was greater for seropositive than seronegative participants (median change in $\mathrm{P} / \mathrm{N}$ from pre to post- $\mathrm{V}_{1}$ seropositive 10.5 vs. seronegative 6.4 ; difference estimate 2.66 (95\% Cl: $-1.6-5.8), \mathrm{W}=181, \mathrm{p}=0.22)$.

Our findings provide preliminary evidence that prior SARS-CoV-2 infection may impact the immune response to the first dose of mRNA-based SARS-CoV-2 vaccine. Specifically, we observed that the response to one vaccine dose among seropositive individuals was almost two-fold higher than that of seronegative individuals and of similar magnitude to the response to two vaccine doses among seronegative individuals.

Our study is limited by a relatively smaller sample size of seropositive compared to seronegative participants and should therefore be replicated by future work. However, we noted a significant difference in response to the first vaccination despite the small sample size, and our results corroborate recent non-peer-reviewed findings. ${ }^{2-4}$ We also extend previous work by demonstrating that the observed immune respone to vaccination among seropositive individuals is robust across varying patterns of antibody responses over time and regardless of timing of past infection, which ranged from 1 to 6 months prior to vaccination.

In conclusion, prior SARS-CoV-2 infection appears to prime the immune response to the first dose of mRNA-based vaccine. Further research on the durability of the response to the first dose of SARS-CoV-2 vaccine among previously infected individuals could help guide the allocation of the limited supply of mRNA-based vaccines. As 27 million Americans have been infected with SARS-CoV-2 to date, ${ }^{11}$ the potential for some individuals to forgo a second vaccination may have substantial impact on vaccine distribution strategies. 
medRxiv preprint doi: https://doi.org/10.1101/2021.02.09.21251319; this version posted February 22, 2021. The copyright holder for this preprint (which was not certified by peer review) is the author/funder, who has granted medRxiv a license to display the preprint in perpetuity.

All rights reserved. No reuse allowed without permission.

\section{Acknowledgements}

We thank the participants for their willingness to contribute to advancing our understanding of the SARS-CoV-2 epidemic and its impact on healthcare personnel, especially during the early and uncertain months of the pandemic. We also appreciate the hard work of the graduate student assistants from the University of North Carolina Gillings School of Global Public Health (Elle Law, BS, Elyse Miller, BA, and Paul Zivich, MPH) and the phlebomists who contributed to the sample collection, protocols, and day-to-day implementation of the study (these individuals received compensation for their work on the study). We acknowledge Premkumar Lakshmanane, PhD who spearheaded development of the ELISA assay and produced and supplied the necessary antigens for the study through funding from the National Cancer Institute [1U54CA260543]. Finally, we thank Subhashini Sellers, MD, MSc and Meghan Rebuli, PhD (University of North Carolina School of Medicine) and Bailey Fosdick, PhD (Colorado State University Department of Statistics) for their support of this study and its analysis. These contributors did not receive any contribution for their role in the study.

\section{Funding/Support}

This project was supported by funds from the following sources:

- 2007 Gillings Gift at the UNC Gillings School of Global Public Health (AEA)

- North Carolina Policy Collaboratory at the University of North Carolina at Chapel Hill with funding from the North Carolina Coronavirus Relief Fund established and appropriated by the North Carolina General Assembly (EJC, RMB, RA, DRZ)

- UNC School of Medicine (RMB)

- A generous donation to the UNC School of Medicine by an anonymous donor (RMB)

- National Institute of Occupational Safety and Health through Grant Award Number [75D30121P10086 0000HCCK-2021] (AEA, EJC)

- National Science Foundation through Grant Award Number NSF 20-4353 (AEA)

- National Institutes of Health through Grant Award Number R01 EB0225021 (AEA)

- National Center for Advancing Translational Sciences (NCATS), National Institutes of Health, through Grant Award Number UL1TR001111 supported the use of the REDCap database. The content is solely the responsibility of the authors and does not necessarily represent the official views of the $\mathrm{NIH}$.

In addition, EJC is supported by the National Heart, Lung, and Blood Institute through Grant Award Number [5T32HL007106-43], RMB is supported by the National Institute of Allergy and Infectious Diseases through Grant Award Number [5K23Al141764-03], and BES is supported by the University of North Carolina at Chapel Hill Center for AIDS Research (CFAR), an NIH funded program P30 Al050410.

The funding organizations/sponsors were not involved in the design and conduct of the study; collection, management, analysis, and interpretation of the data; preparation, review, or approval of the manuscript; or the decision to submit the manuscript for publication.

\section{Competing Interests Statement}

The authors declare no competing interests.

\section{Author Contribution Statement}

EJC designed and supervised the study, composed and revised the paper, and helped to secure study funding.

$\mathrm{DRZ}$ contributed to study design, led the data analysis, and assisted with generation of the figures. 
medRxiv preprint doi: https://doi.org/10.1101/2021.02.09.21251319; this version posted February 22, 2021. The copyright holder for this preprint (which was not certified by peer review) is the author/funder, who has granted medRxiv a license to display the preprint in perpetuity. All rights reserved. No reuse allowed without permission.

RA assisted with data collection and analysis and revised the paper.

EKL contributed to study design, and assisted with generation of the figures.

BES assisted with data analysis and revision of the paper.

RMB conceptualized, designed, and supervised the study, revised the paper, and helped to secure study funding.

AEA conceptualized, designed, and supervised the study, composed and revised the paper, and helped to secure study funding.

All authors, including those in the COVID HCP Study Team, have participated in preparing the manuscript and have reviewed and approved its final, submitted version. 
medRxiv preprint doi: https://doi.org/10.1101/2021.02.09.21251319; this version posted February 22, 2021. The copyright holder for this preprint

(which was not certified by peer review) is the author/funder, who has granted medRxiv a license to display the preprint in perpetuity.

All rights reserved. No reuse allowed without permission.

\section{References}

1. Interim Clinical Considerations for Use of mRNA COVID-19 Vaccines. Published January 28, 2021. Accessed February 4, 2021. https://www.cdc.gov/vaccines/covid-19/info-byproduct/clinical-considerations.html

2. Krammer F, Srivastava K, Simon V, PARIS team. Robust spike antibody responses and increased reactogenicity in seropositive individuals after a single dose of SARS-CoV-2 mRNA vaccine. medRxiv. Published online February 1, 2021. doi:10.1101/2021.01.29.21250653

3. Bradley T, Grundberg E, Selvarangan R, CODIEFY study team. Antibody responses boosted in seropositive healthcare workers after single dose of SARS-CoV-2 mRNA vaccine. medRxiv. Published online February 5, 2021. doi:10.1101/2021.02.03.21251078

4. Saadat S, Rikhtegaran-Tehrani Z, Logue J, et al. Single dose vaccination in healthcare workers previously infected with SARS-CoV-2. medRxiv. Published online February 1, 2021. doi:10.1101/2021.01.30.21250843

5. Marot S, Malet I, Leducq V, et al. Rapid decline of neutralizing antibodies against SARSCoV-2 among infected healthcare workers. Nat Commun. 2021;12(1):844.

6. Wheatley AK, Juno JA, Wang JJ, et al. Evolution of immune responses to SARS-CoV-2 in mild-moderate COVID-19. Nat Commun. 2021;12(1):1162.

7. Ciccone EJ, Zivich PN, Lodge EK, et al. SARS-CoV-2 infection in healthcare personnel and their household contacts at a tertiary academic medical center: Protocol for a longitudinal cohort study (preprint). JMIR Preprints. Published online November 17, 2020. doi:10.2196/preprints. 25410

8. Premkumar L, Segovia-Chumbez B, Jadi R, et al. The receptor binding domain of the viral spike protein is an immunodominant and highly specific target of antibodies in SARS-CoV-2 patients. Sci Immunol. 2020;5(48). doi:10.1126/sciimmunol.abc8413

9. CDC. Interim Guidelines for COVID-19 Antibody Testing. Published November 15, 2020. Accessed January 31, 2021. https://www.cdc.gov/coronavirus/2019ncov/lab/resources/antibody-tests-guidelines.html

10. Bauer DF. Constructing confidence sets using rank statistics. J Am Stat Assoc. 1972;67(339):687-690.

11. Johns Hopkins Coronavirus Resource Center. Johns Hopkins Coronavirus Resource Center. Accessed February 1, 2020. https://coronavirus.jhu.edu/ 
medRxiv preprint doi: https://doi.org/10.1101/2021.02.09.21251319; this version posted February 22, 2021. The copyright holder for this preprint (which was not certified by peer review) is the author/funder, who has granted medRxiv a license to display the preprint in perpetuity. All rights reserved. No reuse allowed without permission.

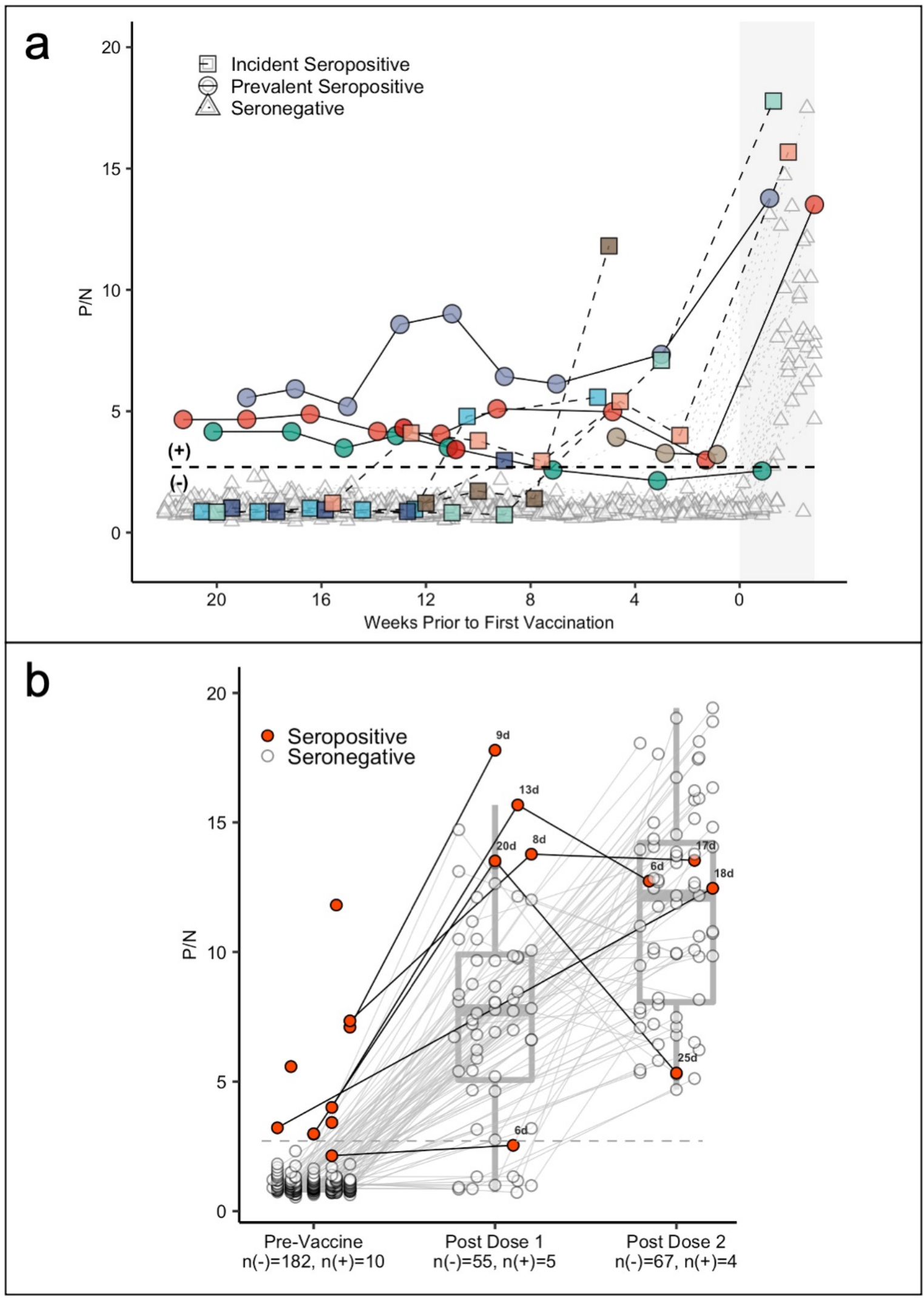


medRxiv preprint doi: https://doi.org/10.1101/2021.02.09.21251319; this version posted February 22, 2021. The copyright holder for this preprint (which was not certified by peer review) is the author/funder, who has granted medRxiv a license to display the preprint in perpetuity.

All rights reserved. No reuse allowed without permission.

Figure 1. Antibody levels of healthcare personnel over time (a) and in response to vaccination (b). Panel (a) demonstrates antibody levels over time in SARS-CoV-2 seronegative (triangles) and seropositive individuals, including those who were seropositive at enrollment (prevalent seropositive, circles) and those who became seropositive during follow-up (incident seropositive, squares). The dotted line is a $\mathrm{P} / \mathrm{N}$ ratio of 2.57 , the cut-off associated with $99.5 \%$ specificity (SARS-CoV-2 Ig-positive above the line, Ig-negative below). The x-axis represents weeks to first vaccine dose; values post-vaccine 1 are shaded. Panel (b) shows box plots with the medians and interquartile ranges of $\mathrm{P} / \mathrm{N}$ ratios pre-vaccination, post-vaccine 1 , and postvaccine 2 by serostatus (seronegative: $n(-)$, seropositive: $n(+))$. The upper and lower whiskers extend to the largest and smallest values no further than 1.5 times IQR from the hinge, respectively. Data beyond the end of the whiskers are outliers. For the pre-vaccine time point, the most recent antibody level prior to vaccination (for those who were vaccinated) or most recent antibody level overall (for those who were not vaccinated) is shown. For the post-vaccine time points, the first measurement after 5 days post-vaccination is included. The black numbers next to the circles indicate the number of days between vaccination and sample collection for seropositive individuals $\left(\mathrm{V}_{1}\right.$ : median 9 , range 6-20; $\mathrm{V}_{2}$ : median 17.5, range 6-25; Supplemental Figure 1). For seronegative participants, the median time between the first vaccine dose and sample collection was 16 days (range 6 to 34 days); between the second vaccine dose and sample collection it was 17 days (range 6 to 33; Supplemental Figure 1). 
Table 1. Demographics, serostatus, and vaccinations for the total study population and the sub-sample of participants with pre- and post-vaccination antibody measurements.

Characteristics

Age, median (IQR)

Female sex, $\mathrm{n}(\%)$

Race/Ethnicity, n (\%)

Black/Non-Hispanic

Asian/Non-Hispanic

White/Non-Hispanic

Other or 2 or more races/Non-Hispanic

Unidentified/Non-Hispanic, Unknown

Hispanic Ethnicity (of any race)

Serostatus prior to vaccination, $\mathbf{n}(\%)$

Seronegative

Seropositive at study enrollment

Incident seropositive

Vaccinations received to date, $\mathrm{n}(\%)$

None

1 dose

2 doses
$183(96)$

$87(94)$

5 (3)

$4(4)$

$5(3)$

$2(2)$
$\mathrm{N} / \mathrm{A}$

6 (3)

2 (2)

$181(94)$

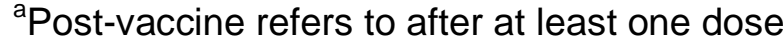

